\title{
Distribusi Material Padatan Tersuspensi di Muara Sungai Sambas, Kalimantan Barat
}

\author{
Petrus Subardjo, Agus Anugroho Dwi Suryo, IbnuPratikno, GenturHandoyo, Karlina Putri Diani
}

DepartemenOseanografi, FakultasPerikanandan IlmuKelautan, UniversitasDiponegoro

Jl. Prof. Sudarto, SH, Tembalang, Semarang, Jawa Tengah, 50275

Email:petrus_subardjo@yahoo.com

\begin{abstract}
Abstrak
Muara Sungai Sambas merupakan gerbang bagi kapal-kapal yang akan melakukan aktivitas bongkar muat hasil tangkapan ikan di PPN Pemangkat. Besarnya konsentrasi material padatan tersuspensi berkaitan dengan tingkat sedimentasi di muara Sungai Sambas yang dapat menyebabkan pendangkalan sehingga aliran sungai ke laut terhambat dan alur pelayaran terganggu. Tujuan penelitian ini adalah untuk mengetahui konsentrasi dan pola sebaran material padatan tersuspensi di muara Sungai Sambas Provinsi Kalimantan Barat. Metode yang digunakan dalam penelitian ini adalah metode studi kasus. Analisis material padatan tersuspensi menggunakan metode Gravimetri. Data utama yang digunakan dalam penelitian ini meliputi data material padatan tersuspensi, arus, dan pasang surut serta data pendukungberupa peta batimetri, dan peta RBI. Hasil penelitian menunjukkan bahwa konsentrasi material padatan tersuspensi terbesar berada di muara sungai dan semakin mengecil kearah laut lepas dengan konsentrasi material padatan tersuspensi saat pasang berkisar antara $67-600 \mathrm{mg} / \mathrm{l}$ serta konsentrasi material padatan tersuspensi saat surut berkisar antara 11-321 mg/l. Jenisarus yang mendominasi di muara Sungai Sambas adalah arus pasang surut. Tipe pasang surut yaitu campurancondongkeharianganda. Kurangnya informasi mengenai arah pergerakan dan besaran konsentrasi material padatan tersuspensi di muara Sungai Sambas menjadikan penelitian untuk mengetahui konsentrasi dan pola sebaran material padatan tersuspensi di perairan tersebut diperlukan.
\end{abstract}

Kata Kunci: Material Padatan Tersuspensi, Arus Pasut, Muara Sungai, Pemangkat

\section{Abstract}

\section{Distribution of Total Suspended Solid in Sambas Estuaries West Kalimantan}

Sambas Estuaries is the entrance for every fisherman boats which will do loading and unloading activity for their fishing at PPN Pemangkat. The amount of total suspended matter concentration is related to the sedimentation at the Sambas estuaries which can cause sedimentation so the river flow hampered and the shipping line disrupted. The purpose of this research is to knowthe concentration and the distribution of total suspended solid at Sambas Estuaries, West Kalimantan. The method which is used in this research is case study method. Data processing is using gravimetric analysis. The main data used in this research are data of total suspended solid, current, tidal and supporting data such as bathymetri map, RBI map. Based on data processing, known that the highest value of total suspended solid was at estuary and decreased toward the sea with the conscentration at tides ranged between $67-600 \mathrm{mg} / \mathrm{l}$ whereas concentration at low tide ranged between 11-321 mg/l. The type tidal which is belong mixed dominant semidiurnal type. Lack of information on the direction of movement and the concentration of total suspended solid at Sambas Estuaries makes research to find out the concentration and distribution of total suspended solid is held at the waters.

Keywords: Total Suspended Solid, Tidal Current, Estuary, Pemangkat

\section{PENDAHULUAN}

Sungai Sambas merupakan sungai yang sering dilalui oleh kapal-kapal yang akan melakukan aktivitas di Pelabuhan Sintete dan PPN Pemangkat yang secara administratif terletak di Kota Pemangkat, Kabupaten Sambas, Provinsi Kalimantan Baratserta bermuara langsung ke Laut
Natuna Utara.Material Padatan Tersuspensi (MPT) merupakan partikel-partikel yang melayang di dalam air yang terdiri dari komponen biotik dan abiotik. Komponen biotik terdiri dari zooplankton, fitoplankton, bakteri, fungi, dan sebagainya. Komponen abiotik terdiri dari detritus dan partikel-partikel anorganik (Hutagalung et al.,
*Corresponding author

buloma.undip@gmail.com http://ejournal.undip.ac.id/index.php/buloma

Diterima/Received : 08-01-2018

Disetujui/Accepted : 19-02-2018 
1997). MPT mempunyai peran penting dalam mempengaruhi kualitas perairan, tingginya konsentrasi material padatan tersuspensi dalam badan air akan menyebabkan kekeruhan yang tidak hanya membahayakan bagi biota tetapi juga menghambat penetrasi cahaya matahari ke badan air dan mengganggu proses fotosintesis (Hardjojo dan Djokosetiyanto, 2005). Pelepasan material padatan tersuspensi menuju lautan yang paling sering dijumpai adalah melalui muara sungai. Material ini sebagian akan mengendap di muara sungai dan sisanya akan diteruskan ke laut.Akibat pengendapan yang terjadi secara terus menerus dan dalam kurun waktu yang cukup lama akan terjadi pendangkalan (Sadri, 2009).

Konsentrasi material padatan tersuspensi berkaitan dengan tingkat sedimentasi di Muara Sungai Sambas yang akan menyebabkan pendangkalan sehingga aliran sungai ke laut terhambat dan alur pelayaran terganggu. Oleh karena itu, diperlukan kajian untuk mengetahui konsentrasi dan sebaran material padatan tersuspensi di muara Sungai Sambas, Kalimantan Barat.

\section{MATERI DAN METODE}

Data utama yang digunakan berupa data lapangan yaitu data sampel material padatan tersuspensi menggunakan botol Nansen dengan 10 titik lokasi berbeda, data arus menggunakan Current Meter Valeport 106 selama $15 \times 24$ jam dengan interval pengamatan 1 jam dan data pasang surut di peroleh dari alat Automatic Tide Master Pressure untuk mengetahui tipe pasang surut, sedangkan untuk data pendukung yaitu peta RBI dan peta batimetri.

Penelitian ini menggunakan metode studi kasus, yaitu metode penelitian terhadap suatu kasus secara mendalam yang berlaku pada waktu, tempat, dan populasi yang terbatas, sehingga memberikan gambaran tentang situasi dan kondisi perairan secara lokal dan hasilnya tidak dapat digeneralisasikan untuk tempat yang berbeda (Hadi, 2004).Metode yang dilakukan untuk pengambilan data utama dilakukan dengan cara pengamatan langsung. Pengamatan dilakukan dengan mengambil sampel material padatan tersuspensi, arus, dan pasang surut.

Metode penentuan lokasi penelitian yang digunakan adalah metode purposive sampling. Metode purposive sampling adalah metode pengambilan sampel berdasarkan pertimbangan peneliti dan tujuan penelitian dimana titik sampel mewakili titik lain pada daerah kajian (Suparyogo, 2001). Titik koordinat lokasi pengamatan ditentukan dengan menggunakan Global Positioning System (GPS). Peta pengambilan sampel material padatan tersuspensi dapat dilihat pada Gambar 1.

\section{Analisis Arus Laut}

Arus yang diperoleh dari pengamatan di lapangan merupakanarus total yaitu arusyang terdiri dari komponen arus pasut dan arus non pasut. Untuk mendapatkan arus pasut maka harus dipisahkan terlebih dahulu. Arus total yang akan dipisahkan harus diuraikan menjadi arus komponen sumbu $\mathrm{x}$ dan arus komponen sumbu y dengan rumus menurut Hadi (2002):

Keterangan:

$$
\begin{aligned}
& v_{x}=v \cdot \sin \alpha \\
& v_{y}=v \cdot \cos \alpha
\end{aligned}
$$

$v_{x}=$ Kecepatanpergerakan partikel air dalam arah $\mathrm{x}$ $(\mathrm{m} / \mathrm{s})$

$v_{y}=$ Kecepatanpergerakan partikel air dalam arah y $(\mathrm{m} / \mathrm{s})$

$\alpha=$ Sudut

\section{Analisis Pasang Surut}

Data pasang surut diolah dan dianalisis menggunakan metode Admiralty. Metode admiralty merupakan metode yang digunakan untuk menghitung konstanta harmonik pasang surut dari pengamatan ketinggian air laut tiap jam selama 29 piantan (29 hari) (Ongkosongo dan Suyarso, 1989).

\section{Analisis Sampel Material Padatan Tersuspensi}

Analisis material padatan tersuspensi menggunakan metode Gravimetri. Perhitungan konsentrasi material padatan tersuspensi menurut Alaerts dan Santika (1984) menggunakan rumus sebagai berikut:

$$
M P T=\frac{(\mathrm{a}-\mathrm{b})}{c} \mathrm{gram} / \mathrm{ml}
$$

Keterangan:

$$
\begin{aligned}
\mathrm{MPT} & =\text { Material padatantersuspensi }(\mathrm{gram} / \mathrm{ml}) \\
\mathrm{a} & =\text { Beratkertassaringdanberat } \mathrm{MPT} \text { di } \\
\mathrm{b} & =\text { Bertassaring (gram) } \\
\mathrm{c} & =\text { Volume sampel air }(\mathrm{ml})
\end{aligned}
$$

\section{HASIL DAN PEMBAHASAN}

\section{Arus Laut}

Pengamatan arus di muara Sungai Sambas, Kalimantan Barat dilakukans selama 15 hari pada tanggal 5-19 Desember 2016. Arus yang dominan 
pada Muara Sungai Sambas adalah arus pasang surut. Kecepatan arus pasang surut maksimum ebesar $0.711 \mathrm{~m} /$ det ke arah timur laut sedangkan kecepatan arus pasang surut minimum sebesar $0.002 \mathrm{~m} /$ det ke arah barat laut. Data kecepatan dan arah arus model pada saat pasnag dan surut di setiap stasiun dapat dilihat pada Tabel 1 dan Tabel 2. Peta pola sebaran arus pada sat pasang dan surut di setiap stasiun dapat dilihat pada Gambar 2 dan Gambar 3.

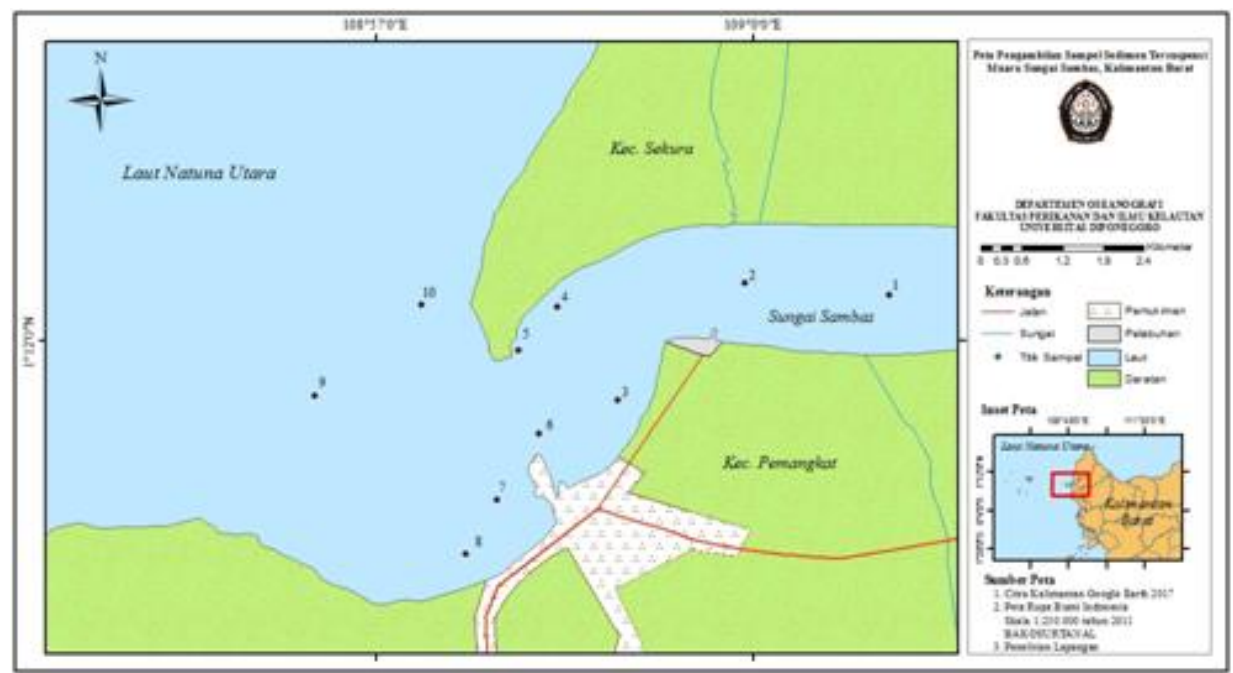

Gambar 1. PetaLokasi Pengambilan Sampel Material Padatan Tersuspensi.

Tabel 1. Kecepatandan Arah Arus Model TiapStasiun

\begin{tabular}{cccccc}
\hline \multirow{2}{*}{ No } & \multirow{2}{*}{ Stasiun } & \multirow{2}{*}{ Bujur } & Lintang & \multicolumn{2}{c}{ KecepatanArus Model (m/s) } \\
\cline { 5 - 6 } & & & PasangMenujuSurut & SurutMenujuPasang \\
\hline 1 & Stasiun 1 & $109^{\circ} 01^{\prime} 04.92^{\prime \prime} \mathrm{T}$ & $1^{\circ} 12^{\prime} 21.61 " \mathrm{U}$ & 0.075910 & 0.0365 \\
2 & Stasiun 2 & $108^{\circ} 59^{\prime} 55.84^{\prime \prime} \mathrm{T}$ & $1^{\circ} 12^{\prime} 27.97 " \mathrm{U}$ & 0.119586 & 0.0498 \\
3 & Stasiun 3 & $108^{\circ} 59^{\prime} 13.29^{\prime \prime} \mathrm{T}$ & $1^{\circ} 12^{\prime} 90.68 " \mathrm{U}$ & 0.164731 & 0.0749 \\
4 & Stasiun 4 & $108^{\circ} 58^{\prime} 54.62^{\prime \prime} \mathrm{T}$ & $1^{\circ} 11^{\prime} 32.81^{\prime \prime} \mathrm{U}$ & 0.101911 & 0.0364 \\
5 & Stasiun 5 & $108^{\circ} 58^{\prime} 26.19^{\prime \prime} \mathrm{T}$ & $1^{\circ} 12^{\prime} 17.40^{\prime \prime} \mathrm{U}$ & 0.084972 & 0.0381 \\
6 & Stasiun 6 & $108^{\circ} 58^{\prime} 33.38^{\prime \prime} \mathrm{T}$ & $1^{\circ} 11^{\prime} 30.28 " \mathrm{U}$ & 0.053880 & 0.0498 \\
7 & Stasiun 7 & $108^{\circ} 57^{\prime} 22.11^{\prime \prime} \mathrm{T}$ & $1^{\circ} 11^{\prime} 13.61 " \mathrm{U}$ & 0.037439 & 0.0106 \\
8 & Stasiun 8 & $108^{\circ} 57^{\prime} 57.87^{\prime \prime} \mathrm{T}$ & $1^{\circ} 10^{\prime} 44.90 " \mathrm{U}$ & 0.012625 & 0.0113 \\
9 & Stasiun 9 & $108^{\circ} 57^{\prime} 22.11^{\prime \prime} \mathrm{T}$ & $1^{\circ} 12^{\prime} 16.46 " \mathrm{U}$ & 0.035043 & 0.0147 \\
10 & Stasiun 10 & $108^{\circ} 56^{\prime} 31.55^{\prime \prime} \mathrm{T}$ & $1^{\circ} 11^{\prime} 34.47 " \mathrm{U}$ & 0.052532 & 0.0193 \\
\hline
\end{tabular}

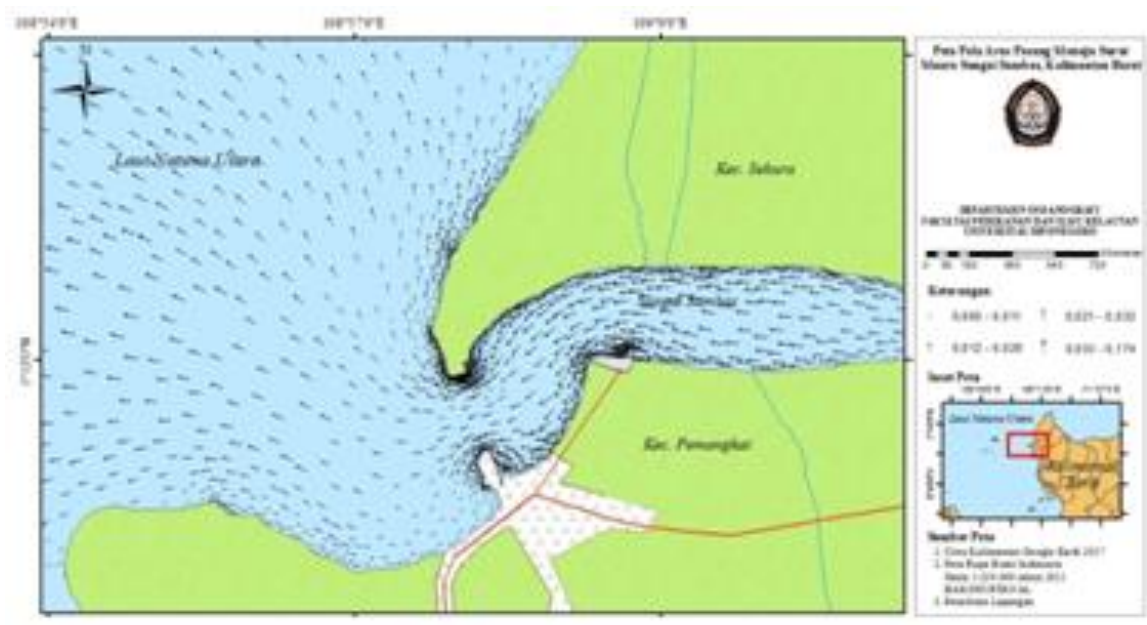

Gambar 2. Peta Pola Arus Pasang Menuju Surut 


\section{Pasang Surut}

Pengamatan pasang surut di muara Sungai Sambas, Kalimantan Barat dilakukan selama 29 hari pada tanggal 4 Desember 2016 s.d. 1 Januari 2017. Kemudian dilanjutkan analisis dengan metode Admiralty untuk mendapatkan karakteristik konstanta harmonic pasang surut (Tabel 3).

Dari hasil pengamatan tersebut juga dapat diketahui nilai Formzahl dari hasil pengamatan ini yaitu sebesar 0.684, nilai tersebut menunjukkan bahwa Muara Sungai Sambas memiliki tipe pasang surut yaitu campuran condong ke harian ganda dimana terjadi dua kali pasang dan dua kali surut dalam satu hari, dan terkadang terjadi satu kali pasang dan satu kali surut dengan tinggi dan waktu kejadian yang berbeda (Gambar4).

\section{Distribusi Material Padatan Tersuspensi}

Analisis laboratorium dilaksanakan di Laboratorium Balai SABO Yogyakarta, dan menghasilkan konsentrasi material padatan tersuspensi saat pasang dan saat surut (Tabel 4 dan 5). Hasil konsentrasi material padatan tersuspensi kemudian diinterpretasikan dalam bentuk peta untuk memperoleh gambaran distribusi material padatan tersuspensi pada saat pasang dan surut dan dapat dilihat pada Gambar 5 sampai dengan Gambar 10.

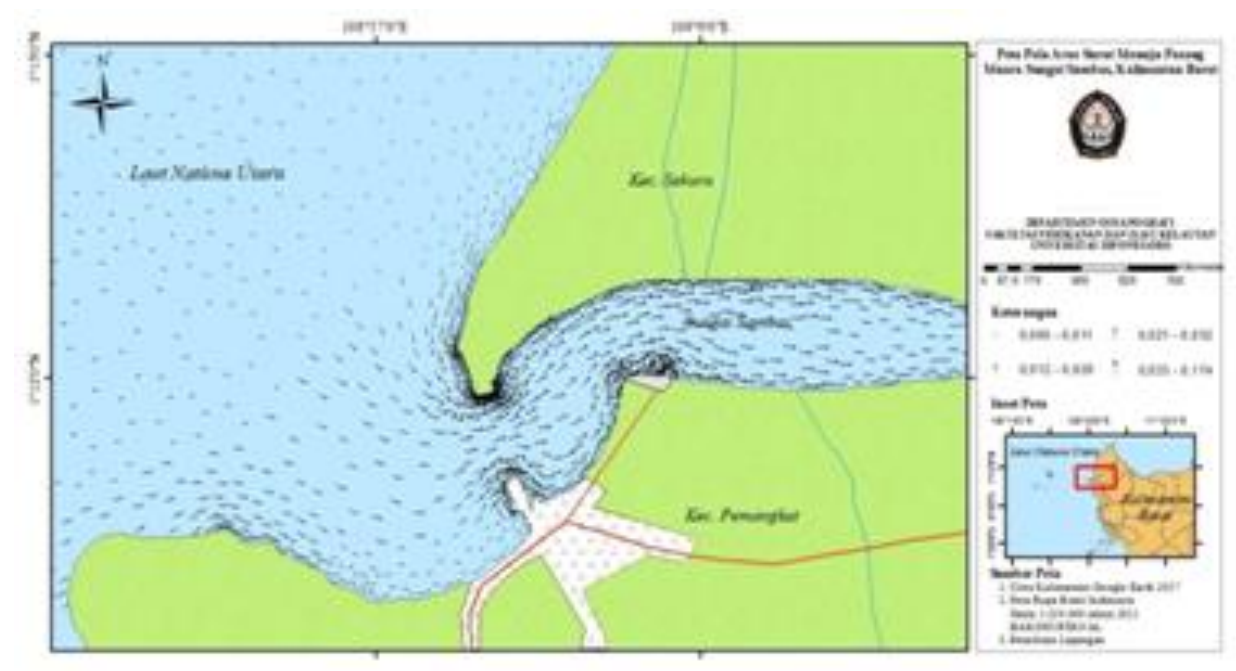

Gambar 3. Peta Pola Arus Surut Menuju Pasang

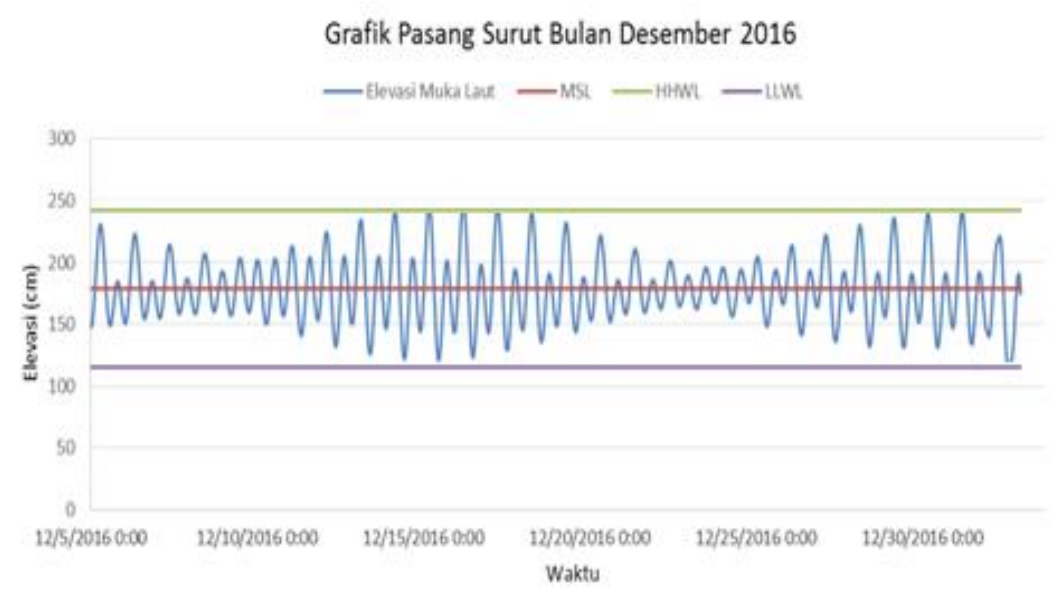

Gambar 4. Grafik Pasang Surut di Muara Sungai Sambas

Tabel 3. Konstanta Harmonik Pasang Surut Muara Sungai Sambas

\begin{tabular}{|c|c|c|c|c|c|c|c|c|c|c|}
\hline & $S_{0}$ & $\mathrm{M}_{2}$ & $\mathrm{~S}_{2}$ & $\mathrm{~N}_{2}$ & $\mathrm{~K}_{1}$ & $\mathrm{O}_{1}$ & $\mathrm{M}_{4}$ & $\mathrm{MS}_{4}$ & $\mathrm{~K}_{2}$ & $P_{1}$ \\
\hline $\mathrm{A}(\mathrm{cm})$ & 178.75 & 28.01 & 12.63 & 4.26 & 9.63 & 18.19 & 0.27 & 0.48 & 3.41 & 3.18 \\
\hline $\mathrm{g}^{\mathrm{o}}$ & & 107.36 & 149.50 & 71.62 & 54.95 & 10.53 & 6.01 & 115.81 & 149.50 & 54.95 \\
\hline
\end{tabular}


Tabel 4. Hasil Konsentrasi Material Padatan Tersuspensi Saat Pasang

\begin{tabular}{ccccc}
\hline \multirow{2}{*}{ Stasiun } & \multirow{2}{*}{ Kedalaman } & \multicolumn{3}{c}{ Konsentrasi Material Padatan Tersuspensi $(\mathrm{mg} / \mathrm{l})$} \\
\cline { 3 - 5 } & & $0,2 \mathrm{~d}$ & $0,6 \mathrm{~d}$ & $0,8 \mathrm{~d}$ \\
\hline Stasiun 1 & 600 & 71 & 151 & 222 \\
Stasiun 2 & 488 & 80 & 218 & 239 \\
Stasiun 3 & 154 & 257 & 359 & 600 \\
Stasiun 4 & 594 & 113 & 170 & 364 \\
Stasiun 5 & 578 & 131 & 202 & 368 \\
Stasiun 6 & 238 & 148 & 228 & 592 \\
Stasiun 7 & 289 & 95 & 233 & 349 \\
Stasiun 8 & 202 & 83 & 242 & 303 \\
Stasiun 9 & 524 & 67 & 120 & 213 \\
Stasiun 10 & 278 & 94 & 237 & 358 \\
\hline
\end{tabular}

Tabel 5. Hasil Konsentrasi Material Padatan Tersuspensi Saat Surut

\begin{tabular}{ccccc}
\hline \multirow{2}{*}{ Stasiun } & \multirow{2}{*}{ Kedalaman } & \multicolumn{3}{c}{ Konsentrasi Material PadatanTersuspensi $(\mathrm{mg} / \mathrm{l})$} \\
\cline { 3 - 5 } & & $0,2 \mathrm{~d}$ & $0,6 \mathrm{~d}$ & $0,8 \mathrm{~d}$ \\
\hline Stasiun 1 & 477 & 11 & 95 & 174 \\
Stasiun 2 & 310 & 20 & 116 & 239 \\
Stasiun 3 & 117 & 46 & 163 & 321 \\
Stasiun 4 & 491 & 27 & 129 & 205 \\
Stasiun 5 & 486 & 28 & 131 & 221 \\
Stasiun 6 & 152 & 43 & 154 & 277 \\
Stasiun 7 & 203 & 35 & 143 & 228 \\
Stasiun 8 & 150 & 29 & 130 & 183 \\
Stasiun 9 & 380 & 21 & 84 & 143 \\
Stasiun 10 & 207 & 31 & 142 & 244 \\
\hline
\end{tabular}

\section{Pembahasan}

Berdasarkan Tabel 4 dan 5, diketahui bahwa konsentrasi MPT terbesar terdapat pada stasiun3 yang berada pada muara sungai dan konsentrasi MPT terkecil terdapat pada stasiun 9 yang lokasinya di laut lepas. Tingginya konsentrasi MPT pada stasiun 3 disebabkan oleh letak stasiun 3 yang berada di Muara Sungai Sambas, dimana daerah tersebut tingkat pengadukannya lebih tinggi dibanding stasiun lain, disamping kedalaman stasiun 3 yang lebih dangkal dibandingkan stasiun lainnya. Selain itu, daerah muara sungai yang juga padat dengan pemukiman nelayan menyebabkan tingkat kekeruhan pada muara sungai ini tergolong tinggi karena pada umumnya sungai digunakan sebagai tempat buangan limbah domestik.

Konsentrasi MPT pada kedalaman 0.8 D lebih tinggi dibandingkan konsentrasi MPT pada kedalaman $0.2 \quad \mathrm{D}$ dan 0.6 D. Semakin bertambahnya kedalaman, konsentrasi MPT semakin tinggi (Tabel 4 dan 5). Hal ini disebabkan oleh adanya proses resuspensi sedimen dimana sedimen di dasar terangkat karena mengalami pengadukan oleh arus sehingga meningkatkan konsentrasi sedimen. Sesuai dengan pendapat Satriadi dan Widada (2004), bahwa arus dan pasang surut menyebabkan pengadukan sedimen di dasar perairan sehingga partikel sedimen tersuspensi di dalam air.

Tingginya konsentrasi MPT pada saat pasang dibandingkan saat surut disebabkan oleh pengaruh arus dan pasang surut, dimana kecepatan arus pada saat pasang lebih tinggi daripada kecepatan arus pada saat surut (Tabel 1 dan 2). Tipe pasang surut di Muara Sungai Sambas adalah condong ke harian ganda, yaitu dalam sehari dapat terjadi dua kali pasang dan dua kali surut. Sirkulasi massa air dari laut menuju sungai pada tipe pasang surut ini lebih besar dikarenakan energi dan arus yang dihasilkan pada saat pasang lebih tinggi. Menurut Satriadi dan 
Widada(2004), pasang tinggi dapat membawa partikel padatan tersuspensi jauh sampai ke hulu sehingga secara langsung mempengaruhi jumlah atau kandungan MPT di daerah tersebut. Sebaliknya pada saat surut, kondisi air yang relatif tenang mempengaruhi penyebaran suspensi. Pergerakan air yang menuju ataupun yang berasal dari laut relatif kecil, sehingga lebih stabil. Keadaan ini memungkinkan terjadinya pengendapan yang lebih intensif ke arah dasar dan menyebabkan konsentrasi MPT menurun. Triatmodjo (1999), menambahkan bahwa energi transport pada saat pasang lebih besar dibandingkan dengan saat surut, sehingga daya
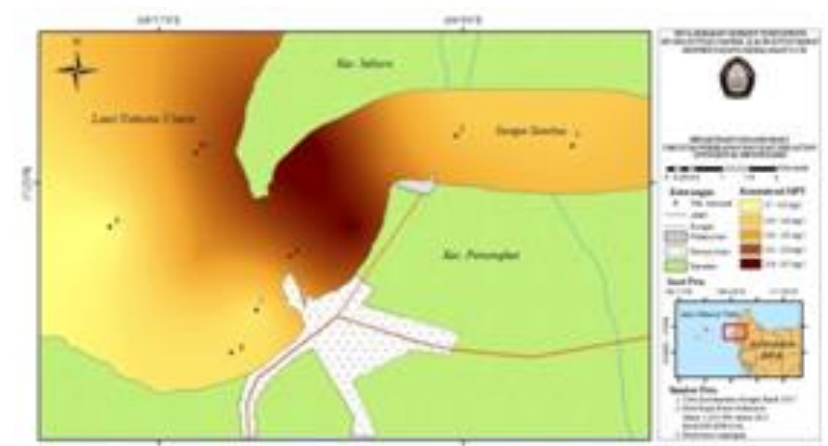

Gambar 5. Peta Sebaran MPT saat Pasang Kedalaman 0.2 D
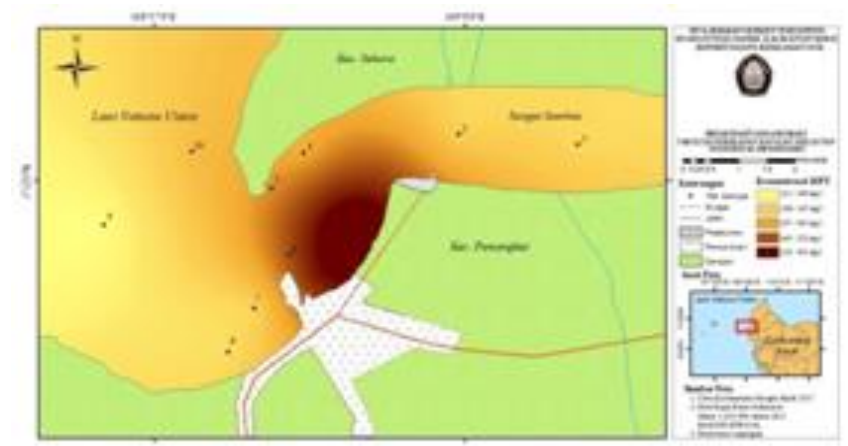

Gambar 7. Peta Sebaran MPT saat Pasang Kedalaman 0.8 D
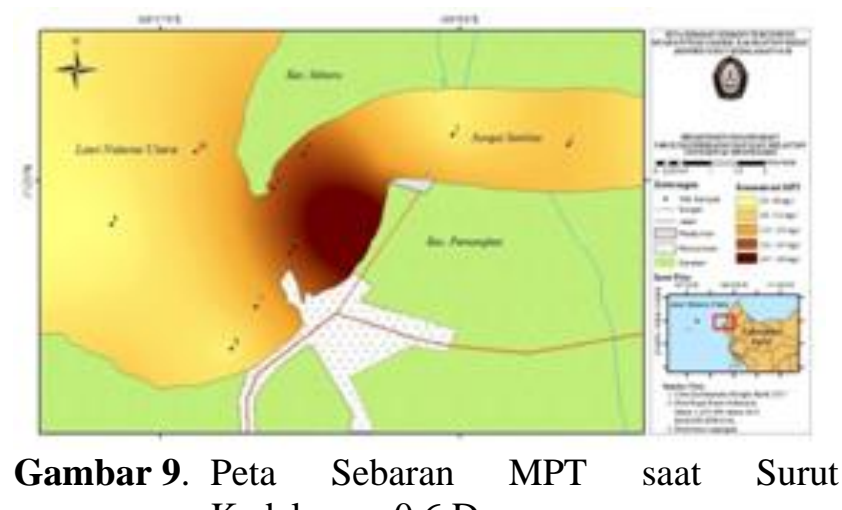
Kedalaman 0.6 D resuspensi saat pasang juga lebih besar dibandingkan dengan saat surut.

Poerbandono dan Djunasjah (2005), menyatakan bahwa sedimen yang berukuran kecil cenderung terangkut sebagai suspensi yang di dalam hal ini kecepatan dan arahnya mengikuti kecepatan dan arah arus. Arah arus di Muara Sungai Sambas dominan kearah barat laut dan timur laut dengan kecepatan arus tertinggi terdapat pada muara sungai (Tabel 1 dan 2). Dinamika pergerakan ini yang membuat hasil dari MPT di setiap stasiun baik pada kedalaman $0.2 \mathrm{D}$ hingga $0.8 \mathrm{D}$ saat pasang maupun surut berbeda (Gambar. 5 sampai dengan Gambar. 10).

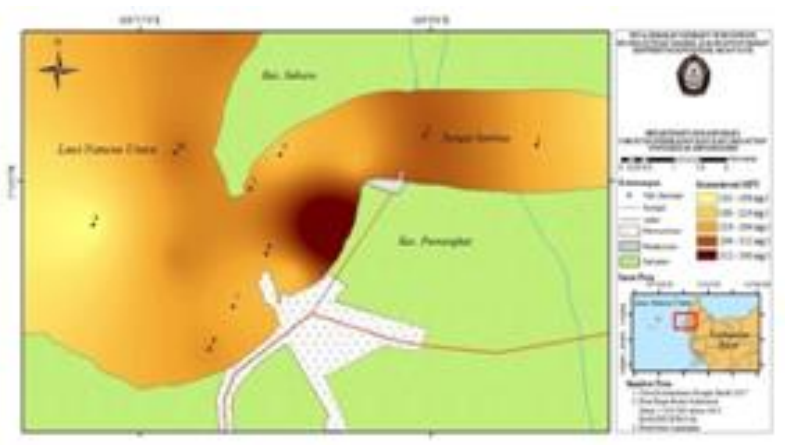

Gambar 6. Peta Sebaran MPT saat Pasang Kedalaman 0.6 D
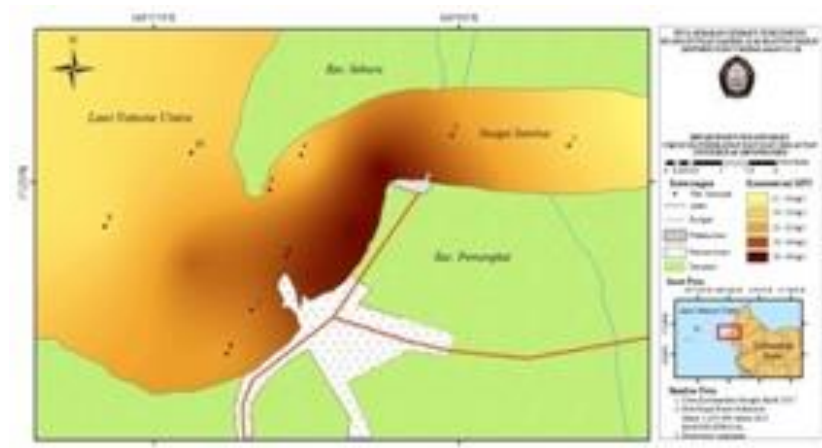

Gambar 8. Peta Sebaran MPT saatSurut Kedalaman 0.2 D
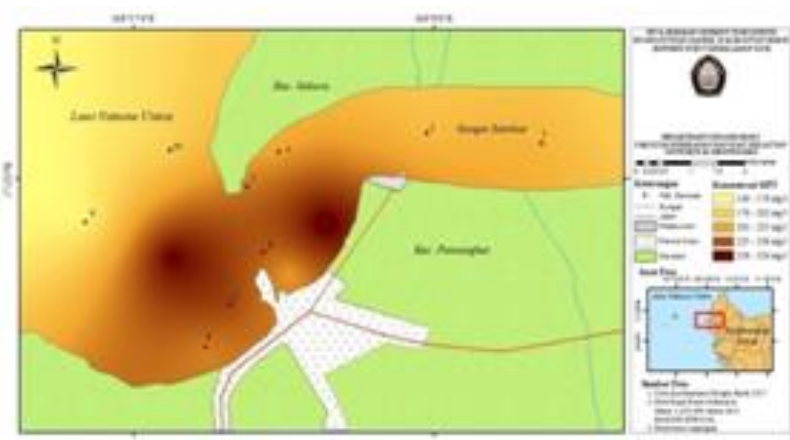

Gambar 10. Peta Sebaran MPT saat Surut Kedalaman $0.8 \mathrm{D}$ 


\section{KESIMPULAN}

Berdasarkan penelitian yang telah dilakukan di muara Sungai Sambas, Kalimantan Barat dapat disimpulkan bahwa konsentrasi material padatan tersuspensi pada kondisi pasang relatif lebih tinggi dibandingkan saat surut dengan kisaran nilai 67-600 mg/l saat pasang dan 11-321 $\mathrm{mg} / \mathrm{l}$ saat surut. Pola distribusi material padatan tersuspensi dipengaruhi oleh arus dengan konsentrasi cukup tinggi di muara sungai yaitu pada stasiun 3, 4, 5, dan 6 dan konsentrasi material padatan tersuspensi semakin berkurang kearah laut lepas.

\section{DAFTAR PUSTAKA}

Alaerts, G \& S. S. Santika. 1987. Metoda Penelitian Air. Usaha Nasional, Surabaya.

Hadi, S. 2002. Arus Laut. Program Studi Oseanografi ITB. Bandung.

Hadi, S. 2004. Metodologi Research Jilid 1. Penerbit Andi, Yogyakarta, $94 \mathrm{hlm}$.

Hardjojo, B. \& Djokosetiyanto. 2005. Pengukuran dan Analisis Kualitas Air. Edisi Kesatu, Modul 1 - 6. Universitas Terbuka. Jakarta.
Hutagalung, H. P., Setiapermana, D., \& Riyono, S. H. 1997. Metodeanalisis air laut, sedimen dan biota. Buku, 2, P2O.

Poerbandono dan Djunarsjah, P. 2005. Survey Hidrografi. Bandung: Refika Aditama.

Ongkosongo, S.R. \& Otto, S., 1989. Project 1: Tides and Tidal Phenomena. Pasang_Surut, Lembaga Ilmu Pengetahuan Indonesia, Pusat Penelitian dan Pengembangan Oseanologi, Jakarta.

Sadri. 2009. Perbandingan Tingkat Sedimentasi Antara Kondisi Eksisting Dengan Alternatif Kondisi Lainnya Pelabuhan Perikanan Nusantara (PPN) Pemangkat Kalimantan Barat. ISBN 978-979-18342-1-6.

Satriadi, A., \& Widada, S. 2004. Distribusi muatan padatan tersuspensi di muara sungai Bodri, Kabupaten Kendal.IlmuKelautan: Indonesian Journal of Marine Sciences, 9(2): 101-107.

Suparyogo, I. 2001. Metode Penelitian Kuantitatif Kualitatif dan R\&D. Bandung: Alfabeta.

Triatmodjo, B. 1999. Teknikpantai. Beta Offset, Yogyakarta, 397. 